\title{
Systematic review of research investigating psychotherapy and information and communication technologies
}

\author{
Revisão sistemática sobre psicoterapia e tecnologias da informação e comunicação
}

\author{
Sílvia Cristina Marceliano Hallberg, ${ }^{1}$ Carolina Saraiva de Macedo Lisboa, ${ }^{2}$ Déborah Brandão de Souza, ${ }^{3}$ Ariela Mester, ${ }^{4}$ \\ Andréia Zambon Braga, ${ }^{5}$ Artur Marques Strey, ${ }^{5}$ Camila Sartori da Silva ${ }^{5}$
}

\begin{abstract}
Introduction: Information and communication technologies (ICTs) are devices, services and knowledge that reproduce, process and distribute information. Psychotherapy has been influenced by these technologies, and there is a tendency for their role to expand.

Objective: To describe the current panorama of the scientific literature on psychotherapy and ICTs.

Method: This is a systematic and descriptive review. Searches were run on the electronic databases Biblioteca Virtual em Saude (BVS), PsycINFO, Scopus, PePSIC, ScienceDirect and Index Psi, using the Boolean operator AND and the descriptors psychotherapy, computers, Internet, cell phones and social networks.

Results: A considerable volume of empirical research was found, published recently in many different parts of the world, especially in the United States. There is very little Brazilian research on the subject. The majority of the studies identified assess the efficacy or describe the development of techniques and psychotherapies, via ICTs, for prevention, diagnosis or treatment of mental and behavioral disorders. The psychopathology most investigated in this area is depression and it was not possible to draw conclusions on a possible trend for research into the subject to increase. The technology most investigated was the Internet and cognitive-behavioral therapy was the most common theoretical approach in these studies.

Conclusions: Systematic reviews of published studies can detect gaps in the research agenda within a specific field of knowledge. Keywords: Systematic review, psychotherapy, computers, Internet, cell phones, social networks.
\end{abstract}

\section{Resumo}

Introdução: As tecnologias da informação e comunicação (TICs) são dispositivos, serviços e conhecimentos que reproduzem, processam e distribuem informações. A psicoterapia tem sido influenciada por essas tecnologias, e existe uma tendência de crescimento de seu papel.

Objetivo: Descrever o panorama atual de produções científicas sobre psicoterapia e TICs.

Método: Uma revisão sistemática e descritiva foi utilizada como método. Buscas foram feitas nas bases eletrônicas de dados Biblioteca Virtual em Saúde (BVS), PsycINFO, Scopus, PePSIC, ScienceDirect e Index Psi, utilizando AND como operador booleano e os descritores psicoterapia, computadores, Internet, telefone celular e redes sociais.

Resultados: Encontrou-se um expressivo volume de trabalhos empíricos, recentemente produzidos em diversas partes do mundo, especialmente nos Estados Unidos. A depressão é a psicopatologia mais investigada nesse campo, e não foi possível inferir sobre uma possível tendência de aumento de pesquisas nessa temática. A Internet foi a tecnologia mais pesquisada, e a terapia cognitivo-comportamental foi a abordagem teórica que mais publicou trabalhos.

Conclusão: Revisões sistemáticas atualizadas sobre o quadro de pesquisas podem apontar lacunas de produções científicas sobre um determinado campo do conhecimento.

Descritores: Revisão sistemática, psicoterapia, computadores, Internet, telefone celular, redes sociais.

\footnotetext{
${ }_{1}^{1}$ Psychologist. MSc candidate, Graduate Program in Psychology, Pontifícia Universidade Católica do Rio Grande do Sul (PUCRS), Porto Alegre, RS, Brazil. Member, Research Team on Interpersonal Relations and Violence: Clinical, Social, Educational and Virtual Contexts, PUCRS, Porto Alegre, RS, Brazil. 2 Psychologist. Professor, Graduate Program in Psychology, PUCRS, Porto Alegre, RS, Brazil. Head, Research Team on Interpersonal Relations and Violence: Clinical, Social, Educational and Virtual Contexts, PUCRS, Porto Alegre, RS, Brazil. ${ }^{3}$ Psychology student, Universidade do Vale do Rio dos Sinos (UNISINOS), São Leopoldo, RS, Brazil. Scholarship holder, Programa Institucional de Bolsas de Iniciação Científica (PIBIC), Conselho Nacional de Desenvolvimento Científico e Tecnológico (CNPq). Member, Research Team on Interpersonal Relations and Violence: Clinical, Social, Educational and Virtual Contexts, PUCRS, Porto Alegre, RS, Brazil. ${ }^{4}$ Psychologist. Member, Research Team on Interpersonal Relations and Violence: Clinical, Social, Educational and Virtual Contexts, PUCRS, Porto Alegre, RS, Brazil. 5 Psychology student. Member, Research Team on Interpersonal Relations and Violence: Clinical, Social, Educational and Virtual Contexts, PUCRS, Porto Alegre, RS, Brazil.

This paper is part of the first author's Master's dissertation, entitled "Percepção e uso de tecnologias da informação e comunicação por psicoterapeutas" (Perception and use of information and communications technology by psychotherapists), presented in January 2015 at the Graduate Program in Psychology, Pontifícia Universidade Católica do Rio Grande do Sul (PUCRS), Porto Alegre, RS, Brazil.

Financial support: Coordenação de Aperfeiçoamento de Pessoal de Nível Superior/Suporte à Pós-Graduação de Instituições de Ensino Particulares (CAPES/PROSUP). Submitted Nov 20 2014, accepted for publication Mar 27 2015. No conflicts of interest declared concerning the publication of this article.

Suggested citation: Hallberg SC, Lisboa CS, de Souza DB, Mester A, Braga AZ, Strey AM, da Silva CS. Systematic review of research investigating psychotherapy and information and communication technologies. Trends Psychiatry Psychother. 2015;37(3):118-125. http://dx.doi.org/10.1590/2237-6089-2014-0055
} 


\section{Introduction}

Psychotherapy is a technique for understanding, analysis and intervention employed by psychologists and accomplished through systematic and controlled application of psychological methods and techniques that are recognized by science, by the practice and by professional ethics. ${ }^{1}$ The technique promotes mental health and provides individuals or groups with the conditions for dealing with psychic conflicts and/or disorders. ${ }^{1}$ Information and communication technologies (ICTs) are devices, services and knowledge related to a certain type of infrastructure, encompassing computers, software and network systems that offer the capacity to reproduce, process and distribute information to people and organizations. ${ }^{2}$ Examples of ICTs include personal computers, cell phones, the Internet, electronic mail, diverse methods for data storage, digital TVs and countless digital technologies for remote access and capture and processing of data, whether text, images or sound. ${ }^{2}$ Information and communication technologies are more and more a part of the daily life of Brazilians and the population that most uses these technologies in the country are those from ten to 24 years old. ${ }^{3,4}$ It is estimated that 77.7 million Brazilians aged ten or over access the web, which is the equivalent of $46.5 \%$ of the total population. ${ }^{5}$ From 2005 to 2011 the number of Internet users in Brazil grew by $143.8 \%$ and the number of Brazilians who own cell phones grew by $107.2 \%$. Currently, $76 \%$ of the population owns at least one cell phone and there is a computer in $45 \%$ of Brazilian homes. ${ }^{3}$

Many different professions have become interested in the possibilities for applying these new technologies to their work. ${ }^{2,6}$ Psychology is no exception and the practice of psychotherapy has been influenced by ICTs, by digital culture and by social media. The velocity with which these new technologies are permeating the world has generated a proliferation of new questions, challenges and opportunities for psychotherapists. 7,8 There are, for example, discussions about and research into the possibilities and limitations of providing psychotherapy sessions at a distance using communication technologies. ${ }^{9-15}$ There are also people reflecting on and studying the ethical limits of therapeutic and extra-therapeutic contacts between psychotherapist and patient via Internet, mobile phone and social networks. ${ }^{7,16-19}$ There is also a field of research studying the possibilities for distance education, training and supervision of psychotherapists. ${ }^{20,21}$ Not to mention studies concerned with use of ICTs in conventional (face-to-face) psychotherapy and investigations of new psychopathologies related to addiction to technologies. ${ }^{22-26}$ Modern psychotherapists are therefore faced with all of these possibilities for the presence, impact or penetration of technology in their daily routines. ${ }^{26-28}$ Furthermore, the tendency is that the role of technology in the field of the psychotherapies will continue to expand. ${ }^{29}$ Despite this scenario, there is no recent survey of the scientific literature on psychotherapy and ICTs. The objective of this study is therefore to describe the current panorama of scientific literature on psychotherapy and ICTs.

\section{Method}

In order to achieve the proposed objectives, a systematic and descriptive review of the literature was conducted. The review process was designed after consulting the guidelines contained in the PRISMA Statement. ${ }^{30}$ Scientific publications were identified by searching the electronic databases Biblioteca Virtual em Saúde (BVS), PsycINFO, Scopus, PePSIC, ScienceDirect and Index Psi, using the Boolean operator AND and the descriptors psychotherapy, computers, Internet, cell phones and social networks. The term information and communication technologies was not used because it is not listed on the DeCS science and health descriptors database. The initial searches yielded 3,349 articles, as shown in Figure 1.

The second stage was to analyze the abstracts of these studies according to the following inclusion criteria: a) date of publication from January 2009 to July 2014 ; b) reference to some type of information and communication technology and psychotherapy and/ or psychotherapists. The results of this analysis were then analyzed according to the following exclusion criteria: a) articles with no abstract; b) non-scientific publications; c) articles published in periodicals that are not peer-reviewed; d) publications written in languages other than English, Portuguese or Spanish; e) articles for which the full text could not be located. Application of these exclusion criteria resulted in rejection of 1,004 articles, as shown in Figure 1 . After removal of articles duplicated across the databases, a total of 982 publications remained for data extraction and analysis, as shown in Figure 1. Despite having used the descriptors listed above, the process of data extraction and analysis identified several studies that dealt with the use of ICTs for treatment of organic pathologies such as cancer and irritable bowel syndrome. Other studies described the use of technology in schools, hospitals and businesses. Furthermore, some of the studies described online data collection or the use of software to analyze findings. In view of this, it was considered necessary to adopt additional exclusion criteria to ensure that the review would reflect the current panorama of scientific literature about ICTs in the context of psychotherapy. 


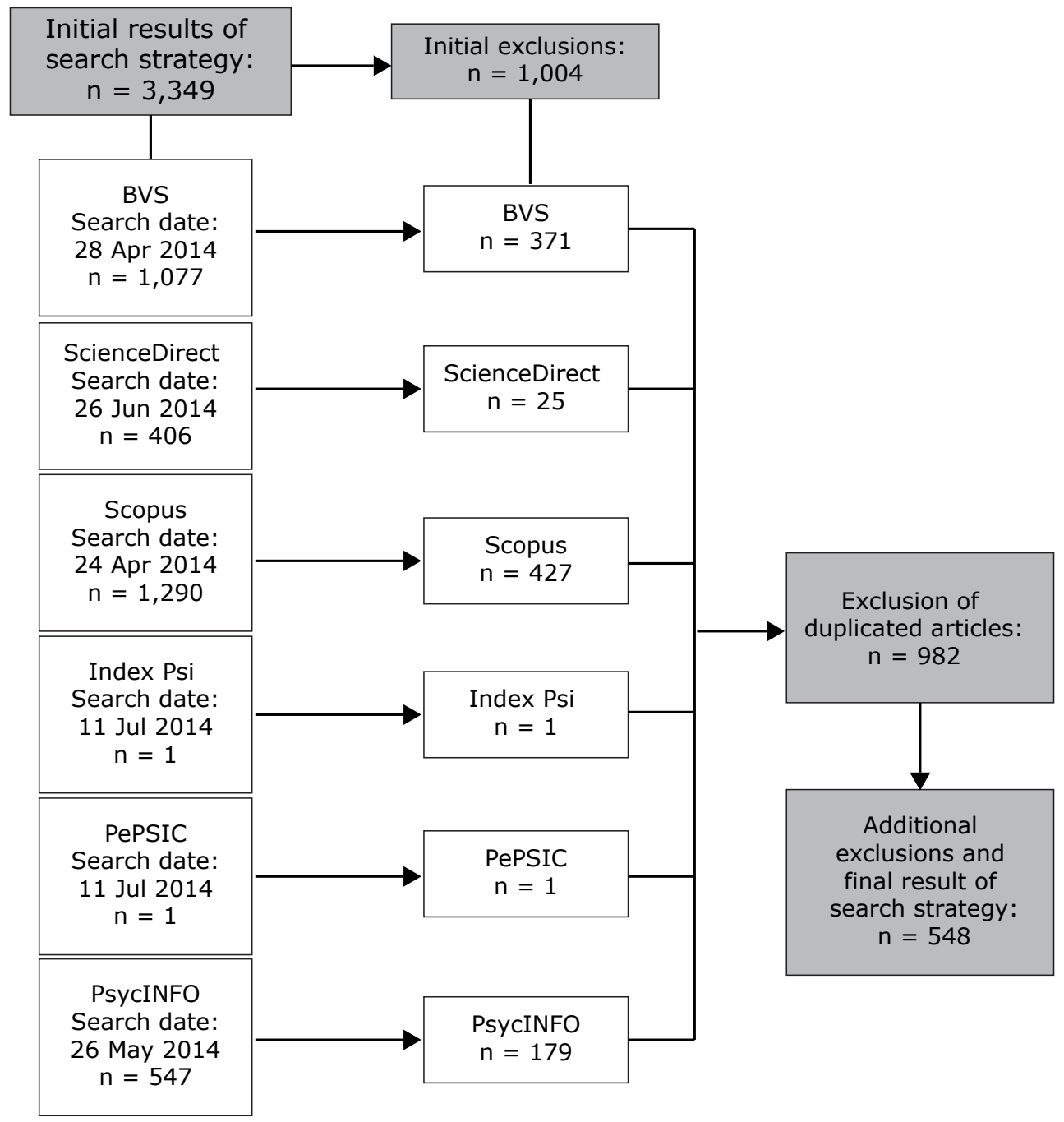

Figure 1 - Search strategy.

The following additional filters were therefore applied: a) publications that describe the use of technology in contexts other than psychotherapy were rejected; b) articles in which technology was used only as a data collection or analytical instruments and was not the focus of the research were eliminated; c) productions that dealt with diagnosis, treatment or prevention of disorders that were neither mental nor behavioral were excluded. The final result was a total of 548 articles, as shown in Figure 1.

The process of extracting and analyzing the data from these 548 articles was conducted using a spreadsheet covering the following: a) year of publication; b) location in which the study was conducted; c) type of study, i.e., whether the article described empirical or theoretical research or a case report; d) type of ICTs investigated; e) theoretical approach used in the study; f) main focus of the study. In order to extract and analyze theoretical approach employed, it was first recorded whether the study was based on a specific theoretical approach. The same was done for research with the objective of investigating or developing some type of psychotherapy via ICTs based on a specific theoretical school. The approaches used were then recorded. For the main focus of the study, details were recorded of whether the study dealt with psychotherapy for adults or for children and adolescents and also whether it focused on treatment or prevention of some type of specific psychopathology. In order to facilitate description of the main focus of the studies reviewed, the 548 articles were classified into six thematic axes, as listed in Table 1. These axes were compiled during reading of the abstracts of the publications identified by the searches. The final findings, as distributed and classified in the spreadsheet, were subjected to descriptive statistical treatment (frequencies). The statistical software employed was the Statistical Package for the Social Sciences (SPSS) Statistics Data Editor version 17.0. 
Table 1 - Classification of the main focus of the studies reviewed

\begin{tabular}{ll}
\hline Thematic axes & Objectives of the studies \\
\hline A & To discuss, investigate, assess the efficacy of or develop techniques and psychotherapies (entire or partial, \\
asymmetrical or symmetrical), via ICTs, for prevention, diagnosis or treatment of mental and behavioral disorders. \\
Such as, for example, a study to assess the efficacy of online psychotherapy for depression. \\
B \\
To discuss, investigate, assess the efficacy of or develop techniques for counseling or psychological guidance via \\
ICTs. Such as, for example, a study to evaluate the efficacy of a technique for counseling, via applications for cell \\
phones, for prevention of relapses to tobacco use. \\
C \\
To discuss, investigate, assess the efficacy of or develop education, training or supervision of psychotherapists via ICTs. \\
Such as, for example, a case study that discusses and reports on supervision of psychotherapists via the Internet. \\
To discuss prevention, diagnosis or treatment of addiction to Internet, video games, cell phones, social networks or \\
E \\
other types of ICT. Such as, for example, a theoretical study about dependence on social networks. \\
To discuss or propose technical guidelines on the presence, use, management or impact of ICTs on conventional/ \\
face-to-face psychotherapy. Such as, for example, a case study discussing and describing the presence of cell \\
phones during psychotherapy with adolescents. \\
To discuss or propose technical guidelines relating to ethical issues thrown up by use of ICTs by psychotherapists. \\
Such as, for example, an article presenting recommended guidelines for maintaining professional limits in the use \\
of social networks by psychotherapists
\end{tabular}

ICTs = information and communication technologies.

\section{Results and discussion}

This systematic review identified a large volume of recently published scientific studies dealing with psychotherapy and ICTs. As can be observed in Figure 1 , both the results of the initial searches ( $n=3,349$ articles identified) and the number identified at the end of the search strategy ( $n=548$ articles chosen) suggest that the subject has been receiving research attention and investment from those that study psychotherapies. Additionally, the majority of studies found were empirical $(74.3 \%)$, indicating that this investment is not restricted to theoretical discussions or case reports on the subject. Theoretical systematic or non-systematic reviews accounted for $22.6 \%$ of the publications located. Just $3.1 \%$ of these were theoretical or technical discussions of reports of psychotherapy cases that involved use of technologies. Another finding that suggests recent interest and research investment by academics in technologies in the field of psychotherapies is that
ICTs are being investigated in many different parts of the world. Scientific studies were found that had been produced in Europe, Africa, North America, Latin America, Asia and Oceania. According to the results of the review, the number one producer of studies on this subject is the United States, with $32.5 \%$ of the articles identified, followed by Australia with $14.4 \%$ and the United Kingdom with $10.2 \%$. Brazil is responsible for just $0.5 \%$ of the publications identified, signifying that $99.5 \%$ of this research was conducted in other countries. This result indicates that, despite the recent and significant increase in ICT use by Brazilians, ${ }^{3,4}$ there is a serious gap in the national research agenda related to the role of technologies in psychotherapy.

With regard to the number of articles published per year, the largest number of studies were published in 2012 (23.5\%), as shown in Figure 2. From 2009 to 2012, there was a continuous increase in number of publications (Figure 2). From 2013 onwards there was possibly a tendency for the number of articles published to drop (Figure 2).

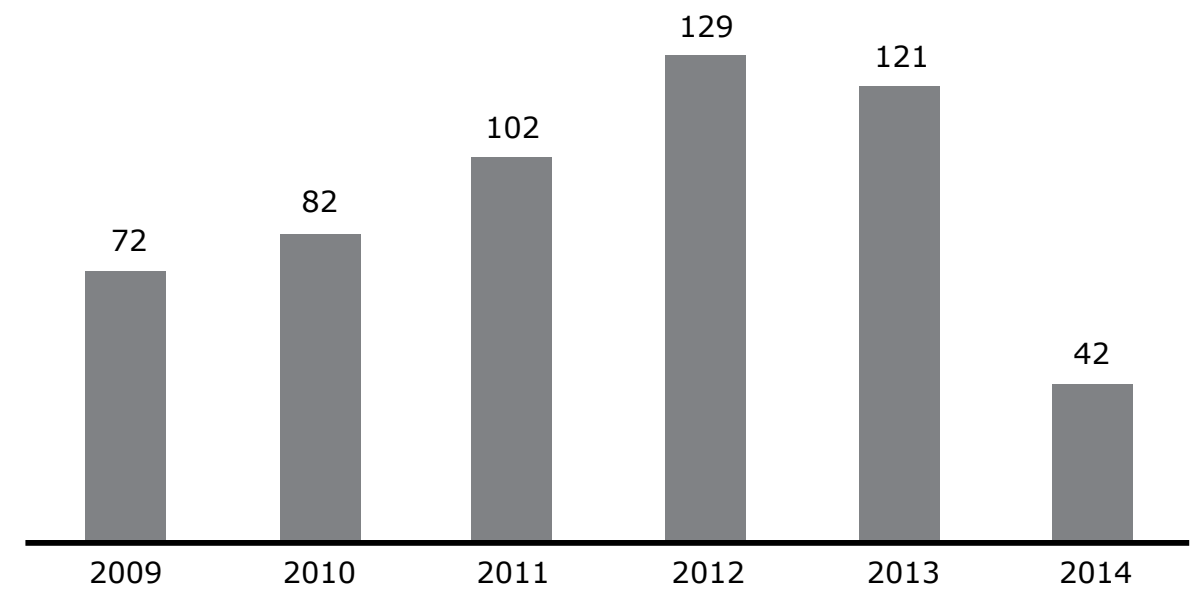

Figure 2 - Number of publications about information and communication technologies and psychotherapies by year. 
It should, however, be pointed out that the findings do not provide a basis for drawing conclusions about a trend to reduction in publications, because the searches run for this review only covered the period up to halfway through 2014. Additionally, when publications were classified as either more or less recent, it was observed that there were more studies available on ICTs and psychotherapies published during the last 3 years. Less recent articles, i.e. those published from 2009 to 2011, accounted for $47 \%$ of the studies identified. More recent research, i.e. studies published from 2012 to July of 2014 , accounted for $53 \%$ of the studies identified.

With regard to the types of technologies that are currently the subject of research, the most common was the Internet $(56.8 \%)$, followed by computer software $(14.4 \%)$ and then virtual reality $(4.4 \%)$, as shown in Table 2. The web was also frequently researched in conjunction with other tools (Table 2). Although the Internet is clearly the most researched technology in the articles investigated in this review, it was nevertheless observed that a wide range of ICTs have been the subject of research investment by scholars (Table 2).

Another interesting finding regards the theoretical foundations of the psychotherapies discussed. Half of the publications based their research on a theoretical approach (56.9\%), with cognitive-behavioral theory the most often mentioned in scientific studies of ICTs and psychotherapies (53.1\%) published over the last 6 years. Psychodynamic approaches were used in just $0.9 \%$ of the studies reviewed.

With regard to the main focus of the studies, the majority were classified as Axis A (75.2\%), i.e. the majority of the articles selected had the objective of assessing the efficacy of or developing techniques and psychotherapies (entire or partial, asymmetrical or symmetrical), via ICTs, for prevention, diagnosis or treatment of mental and behavioral disorders (Figure 3). In Brazil, the Federal Medical Council (Conselho Federal de Medicina, CFM) $)^{31}$ has prohibited virtual medical consultations as a substitute for consultations face-toface with patients and psychotherapies conducted using technological resources for communication at a distance have been classified as exclusively experimental by the Federal Psychology Council (Conselho Federal de Psicologia - CFP). ${ }^{1,31}$ In contrast, psychological guidance of varying types; supervision of the work of psychologists and occasional consultations with clients who are traveling and/or momentarily unable to attend appointments in person are all allowed by law in Brazil. ${ }^{1}$ It is of interest that those psychotherapeutic activities that are permitted in Brazil are the subject of fewer scientific publications than activities that are still considered experimental, such as online psychotherapies. The findings of this review
Table 2 - Technologies investigated in articles about ICTs and psychotherapies

\begin{tabular}{lcc}
\hline Technology & Frequency & $\begin{array}{c}\text { Percentage } \\
\text { valid }\end{array}$ \\
\hline Internet & 311 & 56.8 \\
Internet and cell phones & 17 & 3.1 \\
Internet and social networks & 6 & 1.1 \\
Internet and video games and/or & 3 & 0.5 \\
electronic games & & \\
Computer software & 79 & 14.4 \\
Not specified* & 42 & 7.7 \\
Virtual reality & 24 & 4.4 \\
Cell phones & 21 & 3.8 \\
Video conferencing & 17 & 3.1 \\
Video games and/or electronic & 15 & 2.7 \\
games & & \\
Social networks & 12 & 2.2 \\
Robots & 1 & 0.2 \\
Total & 548 & 100 \\
\hline
\end{tabular}

ICTs = information and communication technologies.

* These articles did not emphasize investigation of any one specific type of ICT. They focused on several types of ICTs or merely referred to the term technologies or information and communication technologies in general.

show that there is little research into psychotherapeutic guidance and counseling via ICTs, accounting for $3.5 \%$ of the articles identified by the searches (Figure 3). The same is true of publications that discuss education, training or supervision of psychotherapists via ICTs, at $3.8 \%$ of the publications found (Figure 3). Similarly, research into the presence, use, management or impact of ICTs on psychotherapy conducted in person only totaled $6 \%$ of the studies found (Figure 3 ).

It is possible that the significant proportion of the articles found that were classified along Axis $A$ is a reflection of a scientific effort by researchers to assess whether techniques for conducting psychotherapy via ICTs could be valid therapies and should be legally permitted. Investigations into online psychotherapy are advanced in countries outside of Brazil. ${ }^{32}$ That is to say that online psychotherapy has been developing internationally for more than ten years, with very promising results. ${ }^{32}$ The United States, the United Kingdom and Australia are the largest producers of studies about the subject, according to the findings of this systematic review, and in those countries psychotherapy online is a regulated practice. ${ }^{33,34}$ The United States is the leading country in terms of investigations of psychotherapy via ICTs and it has effected constant changes to its policies relating to online psychotherapies. ${ }^{35}$ Currently, the North-American standards on ICTs and psychotherapy vary from state to state and psychotherapists must obtain a state license to engage in this practice. ${ }^{33,34}$ 


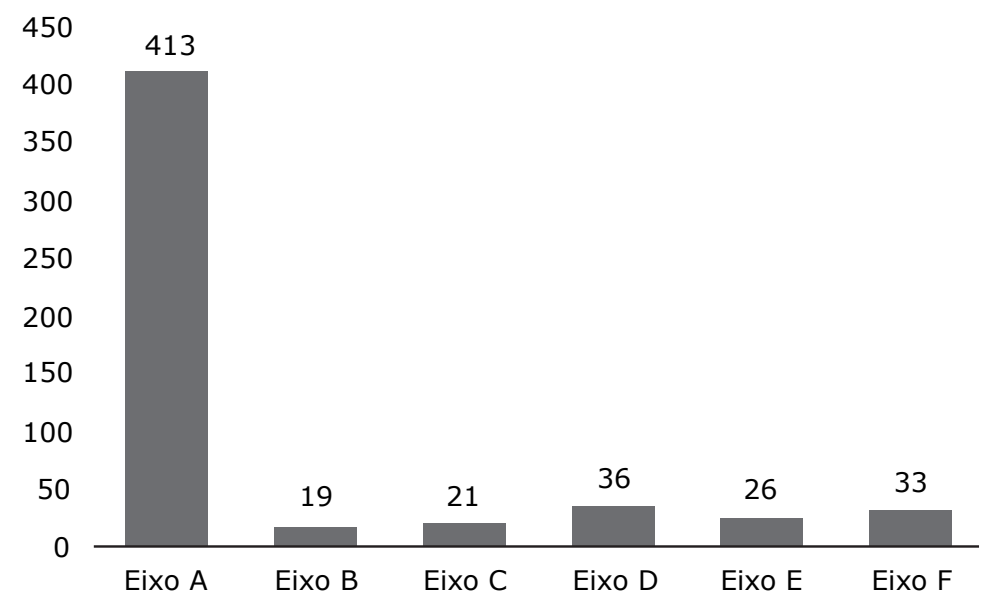

Figure 3 - Main focus of research into information and communication technologies and psychotherapies.

Still with relation to the main focus of the studies, a large proportion of them studied prevention, diagnosis or treatment of a specific psychopathology (73.9\%). Disorders of depression and anxiety were the most commonly investigated mental disorders in the publications reviewed (Table 3). Depression was studied in $17.2 \%$ of the articles identified, making it the most studied psychopathology in the field of psychotherapies and ICTs. Notwithstanding, a wide range of mental and behavioral disorders were the target of research investment by scholars, as shown in greater detail in Table 3.

Another interesting result is that just $14.1 \%$ of the articles identified involved children and adolescents as the target public, suggesting that the largest group of ICT users in Brazill, is the population that has received proportionally the least focus from researchers studying psychotherapies. Consumption of ICTs among children and adolescents is also significant in many American and European countries. ${ }^{4}$ The speed with which children and young people are obtaining access to virtual, convergent, mobile and interconnected technologies is without precedent in the history of technological innovation and diffusion. ${ }^{4}$ The majority of publications reviewed that had children and adolescents as target public were also classified as Axis A (51\%). Depression $(15 \%)$ and addiction to the Internet $(12 \%)$ were the most often investigated disorders. Also of note was the significant number of studies dedicated to diagnosis and/ or treatment of addiction to the Internet, to video games, to cell phones and to social networks (17\%). There were

Table 3 - Mental disorders investigated in articles about ICTs and psychotherapies

\begin{tabular}{|c|c|c|}
\hline Psychopathology & Frequency & Percentage valid \\
\hline Not specified* & 143 & 26.1 \\
\hline Depressive disorders & 96 & 17.6 \\
\hline Anxiety disorders & 96 & 17.6 \\
\hline Disorders related to substances and addictive disorders & 77 & 14.0 \\
\hline More than one mental disorder ${ }^{+}$ & 30 & 5.4 \\
\hline Disorders related to trauma and stressors & 29 & 5.3 \\
\hline Eating disorders & 23 & 4.2 \\
\hline Schizophrenia spectrum and other psychotic disorders & 17 & 3.1 \\
\hline Obsessive-compulsive disorder and related disorders & 17 & 3.1 \\
\hline Disruptive, impulse-control and conduct disorders & 9 & 1.6 \\
\hline Bipolar disorder and related disorders & 5 & 0.9 \\
\hline Neurocognitive disorders & 4 & 0.7 \\
\hline Neurodevelopmental disorders & 2 & 0.4 \\
\hline Total & 548 & 100 \\
\hline
\end{tabular}

ICTs $=$ information and communication technologies

* These articles did not investigate any type of mental disorder.

+ These articles investigated more than one specific psychopathology. 
fewer studies (7\%) covering technical guidelines on use of ICTs in face-to-face psychotherapy with children and adolescents.

\section{Conclusions}

The current panorama of scientific literature on psychotherapy and ICTs can be described as predominantly international, with a large volume of empirical publications, founded on cognitive-behavioral theory and with the objective of discussing, investigating, assessing the efficacy of or developing techniques or psychotherapies via ICTs for the prevention, diagnosis or treatment of mental and behavioral disorders. Disorders of depression and anxiety were the most studied mental disorders in the field of psychotherapies and ICTs. Currently, depression is the most-researched psychopathology and the Internet stands out as the technology most investigated. Notwithstanding, it was observed that academics studying psychotherapies have focused on a wide range of technologies and psychopathologies. Information and communication technologies have been studied in a large number of countries worldwide, but the United States currently stands out as the largest producer of research in the area. There is a greater quantity of scientific literature on psychotherapy and ICTs published over the last 3 years $(2012,2013,2014)$ than in earlier periods. The largest number of studies in the area of ICTs and psychotherapies were published in 2012. There was a continuous increase in the number of these publications from 2009 to 2012 . There was a reduction in the number of these articles published in 2013, but it cannot be concluded with certainty that there a trend towards a reduction in publication of scientific literature in the field of ICTs and psychotherapies has begun, since the search period for this review ended halfway through 2014.

The authors suggest that further studies of a similar nature should be published with the objective of presenting the most up-to-date panorama possible of the scientific literature on psychotherapy and ICTs. This is especially important when one considers the speed with which new technologies are developed. Finally, it is necessary to consider the practical implications of this systematic review. Up-to-date systematic reviews of the scientific literature can detect gaps in the research agenda within a specific field of knowledge. This study has shown a predominance of investment in research into psychotherapy via ICTs. The review has also shown a lack of studies in other areas of psychotherapeutic knowledge, such as the low proportion of publications dealing with counseling via ICTs.

\section{References}

1. Conselho Federal de Psicologia (CFP). Resolução do CFP no 011/ 2012 [Internet]. [cited 2013 Jun 2]. http://site.cfp.org.br/wpcontent/uploads/2012/07/Resoluxo_CFP_nx_011-12.pdf

2. Veloso R. Tecnologias da informação e comunicação: desafios e perspectivas. São Paulo: Saraiva; 2011.

3. Comitê Gestor da Internet no Brasil (CGI). Pesquisa sobre o uso das tecnologias de informação e comunicação no Brasil: TIC domicílios e TIC empresas 2011 [Internet]. [cited 2013 May ]. http://www.cetic.br/tics/usuarios/2011/total-brasil/

4. CGI. TIC Kids Online Brasil 2012: pesquisa sobre o uso da internet por crianças e adolescentes no Brasil [Internet]. [cited 2014 Oct ]. http://www.cetic.br/media/docs/publicacoes/2/tickids-online-2012.pdf

5. Instituto Brasileiro de Geografia e Estatística (IBGE). Pesquisa nacional por amostra de domicílios: acesso à internet e posse de telefone móvel celular para uso pessoal (PNAD) [Internet]. [cited 2013 May ]. ftp://ftp.ibge.gov.br/Acesso_a_internet_e_posse_ celular/2011/PNAD_Inter_2011.pdf

6. Carlotto MS, Wendt GW, Lisboa C, Moraes MA. Preditores de adição ao trabalho em trabalhadores que utilizam tecnologias da informação e comunicação. Temas Psicol. 2014;22:387-77.

7. Kolmes K. Social Media in the Future of Professional Psychology. Prof Psychol Res Pr. 2012;43:606-12.

8. McMinn MR, Bearse J, Heyne LK, Smithberger, A, Erb AL. Technology and independent practice: survey findings and implications. Prof Psychol Res Pr. 2011;42:176-84.

9. Almeida LP, Rodrigues JT. Narrativa e internet: possibilidades e limites do atendimento psicoterápico mediado pelo computador. Psicol Cienc Prof. 2003;23:1-7.

10. Lovejoy TI, Demireva PD, Grayson JL, McNamara JR. Advancing the practice of online psychotherapy: an application of Rogers' diffusion of innovations theory. Psychotherapy (Chic). 2009;46:111-24.

11. Marot SV, Ferreira MC. Atitudes sobre a aprovação da psicoterapia online na perspectiva da Teoria da Ação Racional. Rev Interamericana Psicol. 2008;42:317-24.

12. Meyer SB, Prado OZ. Avaliação da relação assimétrica na terapia assíncrona via internet. Psicol Estud. 2006;11:247-57.

13. Oliveira PCS. O divã virtual e a linguagem do atendimento psicanalítico on-line no ciberespaço [dissertation]. Rio de Janeiro: Universidade Estadual do Norte Fluminense Darcy Ribeiro, Centro de Ciências do Homem; 2009.

14. Pinhatti MM, Pieta MAM, Gomes WB. Terapia pela Internet: limites e possibilidades na percepção de psicoterapeutas. In: XXIII Salão de Iniciação Científica da UFRGS; 2011; Porto Alegre, Brasil.

15. Zur O. Telepsychology or telementalhealth in the digital age: the future is here. California Psychol. 2012;45:13-5.

16. Jent JF, Eaton CK, Merrick MT, Englebert NE, Dandes SK, Chapman $A V$, et al. The decision to access patient information from a social media site: what would you do? J Adolesc Health. 2011;49:414-20.

17. Kolmes K, Taube DO. Seeking and finding our clients on the internet: boundary considerations in cyberspace. Prof Psychol Res Pr. 2014;45:3-10.

18. Sfoggia A, Kowacs C, Gastaud MB, Laskoski PB, Bassols AM, Severo CT, et al. Therapeutic relationship in the web: to face or not to face? Trends Psychiatry Psychother. 2014;36:3-10.

19. Taylor L, Mcminn MR, Bufford RK, Chang KBT. Psychologists' attitudes and ethical concerns regarding the use of social networking web sites. Prof Psychol Res Pr. 2014;41:153-9.

20. Donnamaria CP, Terzis A. Experimentado 0 dispositivo terapêuticos de grupo via internet: primeiras considerações de manejo e desafios éticos. Rev SPAGESP. 2011;12:17-26.

21. Barnett JF. Utilizing technological innovations to enhance psychotherapy supervision, training, and outcomes. Psychotherapy (Chic). 2011;48:103-8.

22. King DL, Delfabbro PH, Griffiths MD, Gradisar M. Cognitivebehavioral approaches to outpatient treatment of internet addiction in children and adolescents. J Clin Psychol. 2012;68:1185-95.

23. King DL, Delfabbro PH, Zwaans T, Kaptsis D. Clinical features and axis I comorbidity of Australian adolescent pathological Internet and video game users. Aust N Z J Psychiatry. 2013;47:1058-67.

24. Ceranoglu T. Video games in psychotherapy. Rev Gen Psychol. 2010;14:141-6.

25. Bunge E, López P, Mandil J, Gomar M, Borgialli R. La implementación de recursos tecnológicos en la clínica niños $Y$ adolescentes. Rev Argent Clin Psicol. 2009;18:59-68. 
26. Levisky RB, Rocha da Silva MC. A invasão das novas formas de comunicação no setting terapêutico. Vínculo - Rev NESME. 2010;7:63-70.

27. Leitão CF, Abreu RS, Nicolaci-da-Costa AM. Profissionais à deriva: professores e psicoterapeutas na sociedade em rede. Interações. 2005; 10:151-74.

28. Rosegrant J. Techonologically altered reality inside the therapist's office. Psychoanal Psychol. 2012;29:226-40.

29. Silverman WH. The future of psychotherapy: one editor's perspective. Psychotherapy (Chic). 2013;50:484-9.

30. Moher D, Liberati A, Tetzlaff J, Altman DG; PRISMA Group. Preferred reporting items for systematics reviews and metaanalyses: the PRISMA statement. PLoS Med. 2009;6:e1000097.

31. Conselho Federal de Medicina (CFM). Resolução n 1.974/2011. Diário Oficial da União, 19 de agosto de 2011. [cited 2015 Jan 28]. http:// www.portalmedico.org.br/resolucoes/CFM/2011/1974 2011.htm

32. Pieta M,am Gomes WB. Psicoterapia pela Internet: viável ou inviável? Psicol Cienc Prof. 2014;34:18-31.

33. Counselling Resource. Professional licensing in mental health [Internet]. [cited 2015 Jan 28]. http://counsellingresource.com/ lib/therapy/aboutcouns/licensure/
34. Board of Behavioral Sciences (BBS). (2012). Consumer information regarding online psychotherapy [Internet]. [cited 2015 Jan 28]. http://www.bbs.ca.gov/consumer/consumer_psych_online.shtml 35. DeAngelis T. Practicing distance therapy, legally and ethically: psychology is developing guidelines for practitioners in this rapidly changing area [Internet]. [cited 2015 Jan 28]. http:// www.apa.org/monitor/2012/03/virtual.aspx

\section{Correspondence:}

Carolina Saraiva de Macedo Lisboa Programa de Pós-Graduação em Psicologia (PUCRS) Av. Ipiranga, 6681, prédio 11 , sala 929, Partenon 90619-900 - Porto Alegre, RS - Brazil

E-mail: carolina.lisboa@pucrs.br 